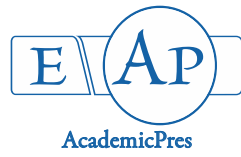

\title{
Process of Modeling and Optimizing the Osmotic Dehydration Pre-treatment of Okra Drying
}

\author{
Adesoji Matthew OLANIYAN ${ }^{1 *}$, Bamidele David OMOLEYOMI ${ }^{2}$, \\ Musiliu Olushola SUNMONU ${ }^{3}$
}

\author{
${ }^{1}$ Federal University Oye-Ekiti, Faculty of Engineering, Department of Agricultural and Bioresources Engineering, Ekiti State, \\ Nigeria; adesoji.olaniyan@fuoye.edu.ng (*correspondingauthor); amolan397@hotmail.com \\ ${ }^{2}$ University of Ilorin, Faculty of Engineering and Technology, Department of Agricultural and Biosystems Engineering, Ilorin, \\ Nigeria; omodeleyomi@gmail.com \\ ${ }^{3}$ University of Ilorin, Faculty of Engineering and Technology, Faculty of Engineering and Technology, Department of Food and Bioprocess \\ Engineering, Ilorin, Nigeria; sholams2000@yahoo.co.uk
}

\begin{abstract}
Okra [Abelmoschus caillei (A. Chev.) Stevels] drying was studied by a factorial experiment under randomized complete block design using a laboratory-scale hot-air dryer. Two osmotic solution concentrations ( 40 and $60{ }^{\circ} \mathrm{Brix}$ of sucrose), three osmotic process durations $(60,120$ and $180 \mathrm{~min})$ and four drying temperatures $\left(50,60,70\right.$ and $\left.80{ }^{\circ} \mathrm{C}\right)$ were considered with each trial conducted in triplicates. Drying rate was determined as the ratio of change in mass of okra to the change in drying time as drying progresses. The ash content, crude fibre, crude fat, crude protein, bulk density, least gelation concentration and water absorption capacity were investigated as quality parameters. Model equations were developed using Essential Regression (ESSREG) analysis and Statistical Package for Social Sciences (SPSS) to relate output parameters to process variables. The results showed that an optimum drying rate of $16.69 \mathrm{~g} / \mathrm{h}$ could be achieved by subjecting okra to osmotic dehydration pretreatment using a solution of $40{ }^{\circ} \mathrm{Brix}$ sucrose for $149.10 \mathrm{~min}$ and dried with a temperature of $80{ }^{\circ} \mathrm{C}$. The ash content of $3.76 \%$ could be obtained at $40{ }^{\circ} \mathrm{Brix}, 180 \mathrm{~min}$ and $50{ }^{\circ} \mathrm{C}$. An optimum value of $29.65 \%$ was obtained for crude fibre at an osmotic solution concentration of $60^{\circ} \mathrm{Brix}$, osmotic process duration of $180 \mathrm{~min}$ and drying temperature of $80{ }^{\circ} \mathrm{C}$. Crude fat content of okra has $4.03 \%$ as its optimum value and this corresponds to a combination of $60{ }^{\circ}$ Brix osmotic solution concentration, $180 \mathrm{~min}$ osmotic process duration and $74.60{ }^{\circ} \mathrm{C}$ drying temperature. An osmotic solution concentration of 60 ${ }^{\circ} \mathrm{Brix}$, osmotic process duration of $60 \mathrm{~min}$ and drying temperature of $80{ }^{\circ} \mathrm{C}$ should be selected to give the optimum crude protein of $14.12 \%$. Predicted values of drying rate, ash content, crude fibre, crude fat, crude protein and water absorption capacity (WAC) compared favourably with the observed values. This implies the models reliably predicted the drying characteristics of okra very well in terms of these output parameters.
\end{abstract}

Keywords: drying rate; duration; hot-air dryer; model equations; temperature; quality parameters

\section{Introduction}

Fruits and vegetables form the most substantial parts of human diets in the whole world and, unfortunately, they disappear too soon immediately after harvest, hence, they are categorized under perishable commodities because of rapid postharvest losses. Some countries, especially Israel, refer to this group of crop as fresh commodities or fresh produce. In Nigeria, postharvest losses in perishable commodities (especially tomato, onion, pepper, okra, mango, orange, banana, plantain, etc) have been found to be more than $50 \%$. Most of these losses occur during handling, transportation, storage and processing.
Okra [Abelmoschus caillei (A. Chev.) Stevels] has been a popular vegetable crop in the tropics because of its easy cultivation, dependable yield, adaptability to varying moisture conditions and resistance to diseases and pests. The crop is suitable for cultivation as a garden crop as well as on large commercial farms. Okra is the most important fruit vegetable crop and a source of calorie $(4550 \mathrm{kcal} / \mathrm{kg})$ for human consumption and it ranks first before other vegetable crops (Babatunde et al., 2007). According to Anwar et al. (2009), okra seed oil is used for biodiesel production by an alkali-catalyzed and-methanol-induced transesterification process. The health benefit of okra has been investigated by Alqasoumi (2011) who discovered that 
494

that the ethanolic extract of okra (EEO) has a preventive action against liver injury.

The most important aspect of the okra value chains is the postharvest process and, therefore, the problem is to develop methods for preventing or minimizing postharvest losses in the commodity. Drying is one of the most viable ways of preventing postharvest loss and at the same time preserving the quality of okra as dried okra (orunla) is widely accepted among the Yorubas of the South-West Nigeria. Olaniyan and Omoleyomi (2014) developed a prototype tomato dryer and this has been found suitable for drying okra and other vegetables while drying conditions can also be optimized using the dryer.

Mohebbi et al. (2015) investigated the effects of modified atmospheric packaging on storability and quality of Cornelia cherry (Cornus mas L.) fruits using unpackaged cherries as a control. From the results of their experiments, they discovered that in the modified atmospheric packaging, the stored fruits retained their weight and quality but the weight and quality of the fruits were drastically reduced in the unpackaged samples. Afify et al. (2015) studied the effect of some pre-processing pre-treatments on the characteristics of sorghum biscuits using sensory characteristics, physical properties and hardness as quality evaluation criteria. In the experimentation, the researchers used 50\% whole meal flour of raw, soaked, cooked, germinated and fermented sorghum for physical characterization and sensory evaluation. From the result of the experiment, they discovered that, in preparing acceptable quality biscuits, $50 \%$ sorghum whole meal flour could be incorporated. Doymaz (2005) investigated airdrying characteristics of okra using a temperature and relative humidity of $50-70{ }^{\circ} \mathrm{C}$ and $8-25 \%$ respectively in a laboratory scale hot-air dryer. He discovered that drying took place in the falling rate period while effective diffusivity increased with increasing temperature. His concluded from the study that single layer drying of okra was best described by the Page model.

As a perishable crop in its natural state after harvest, okra is available during the production season but very scarce during the off-season. This crop should be available all the year round in a very good postharvest condition due to its nutritive value and drying is one of the most practically feasible methods of its postharvest preservation. Olaniyan and Omoleyomi (2013) have investigated the drying process of okra under different conditions. The present study is aimed at fitting model equations to experimental data in order to optimize the drying process of okra. Therefore, the objectives of this study were: (i) to develop mathematical models to estimate the effects of osmotic dehydration pre-treatments (osmotic solution concentrateons and osmotic process duration) and drying temperature on drying rate and post-drying quality attributes of okra; and (ii) to optimize the drying process for maximum drying rate and maximum post-drying qualities.

\section{Materials and Methods}

\section{Biologicalmaterial}

Ten $\mathrm{kg}$ of freshly harvested okra pods were collected from Ipata market in Ilorin East Local Government Area of
Kwara State. The market women procure their produce directly from farmers in Ilorin East, Ilorin West, Ilorin South and Edu Local Government Areas of Kwara State. After sorting, the okra samples were rinsed in clean water at room temperature and cut with the okra slicer to a thickness of $7 \mathrm{~mm}$. One hundred $\mathrm{g}$ of the sample were weighed and immersed in a hypertonic solution of sucrose of two different concentrations ( 40 and $60{ }^{\circ}$ Brix - mass ratio of fruit to sucrose was 1:1) for two simultaneous countercurrent flows - an exit of water from the product to the solution and a migration of natural solids into the product. Samples were removed from the sucrose solution after separately subjecting them to the three different osmotic process durations $(60,120$ and $180 \mathrm{~min})$.

\section{The drying process}

The dryer (Fig. 1) used for this study and details of drying procedure had been described by Olaniyan and Omoleyomi (2013). One hundred g of samples of okra pretreated with two levels of osmotic solution concentration ( 40 and $60{ }^{\circ} \mathrm{Brix}$ ) for three levels of osmotic process duration $(60,120$ and $180 \mathrm{~min})$ were weighed and dried at four levels of drying temperature $(50,60,70$ and 80 $\left.{ }^{\circ} \mathrm{C}\right)$ with each experiment carried out in triplicates. The temperature of the exhaust air from the dryer was also measured and recorded. The drying samples were weighed at intervals of $1 \mathrm{~h}$ and drying continued until the desirable moisture contentment of $10 \%(\mathrm{wb})$ was reached.

Drying rate has been determined earlier by Olaniyan and Omoleyomi (2013) as:

$$
\mathrm{R}=(\mathrm{dM} / \mathrm{dt})=\left(\mathrm{m}_{\mathrm{i}}-\mathrm{m}_{\mathrm{f}}\right) / \mathrm{t}
$$

where $\mathrm{R}$ is the drying rate in $\mathrm{g} / \mathrm{h} ; \mathrm{dM}$ is change in mass of okra in $g$; $d t$ change in time in $h$; $t$ is the total time of drying in $\mathrm{h}$; $\mathrm{mi}$ and $\mathrm{mf}$ are the initial and final mass of okra samples respectively in $\mathrm{g}$.

\section{The post-drying qualities of okra}

The post-drying qualities determined included: crude protein content, crude fat content, crude fibre content, ash content, bulk density, least gelation concentration (LGC) and water absorption capacity (WAC). The methods for determining these quality parameters follow the standard for physico-chemical analysis of biological materials.

\section{Statistical analyses}

Using the SPSS computer software package, model equations were developed employing essential regression analysis (ESSREG). The model equations were used to predict the drying rate and post-drying qualities based on different osmotic solution concentrations, different osmotic process durations and different drying temperatures. Furthermore, the drying process was optimized for maximum drying rate and maximum post-drying qualities considered in the study.

\section{Results and Discussion}

\section{Model development}

The model was based on a three-factor (osmotic solution concentration, osmotic process duration and drying temperature) essential regression model. From the regression analysis, the following regression models 
(Equations 2 - 9) were obtained for drying rate, crude protein content, crude fat content, crude fibre content, ash content, bulk density, least gelation concentration (LGC) and water absorption capacity (WAC) respectively.

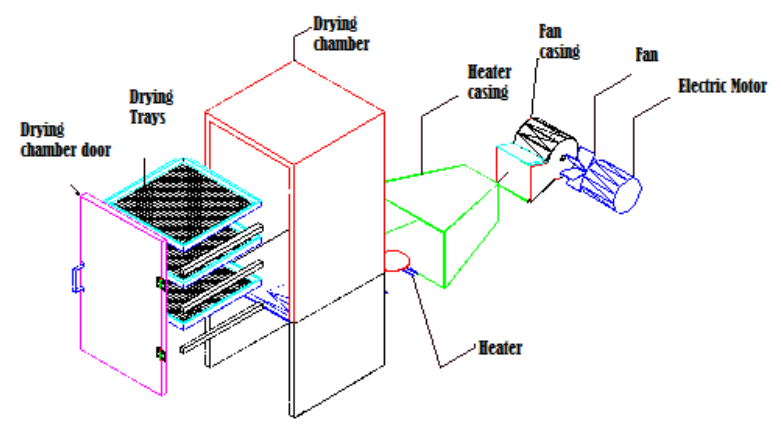

Fig. 1. General view of the laboratory dryer showing the component parts

$$
\begin{aligned}
& Y_{1}=8.66+6.68 \mathrm{E}-06 \alpha \beta^{2}-2.74 \mathrm{E}-05 \alpha \beta \gamma+1.84 \mathrm{E}-05 \alpha \gamma^{2}- \\
& 5.21 \mathrm{E}-06 \beta^{2} \gamma-2.06 \mathrm{E}-05 \beta \gamma^{2}, \mathrm{R}_{\mathrm{adj}}{ }^{2}=96.10 \%
\end{aligned}
$$

$\mathrm{Y}_{2}=7.16+1.50 \mathrm{E}-02 \beta-9.21 \mathrm{E}-07 \alpha \beta^{2}-8.24 \mathrm{E}-05 \beta \gamma+$ $6.64 \mathrm{E}-04 \alpha \gamma+1.36 \mathrm{E}-04 \alpha \beta-6.69 \mathrm{E}-02 \gamma-7.83 \mathrm{E}-02 \alpha, \mathrm{R}_{\mathrm{adj}}{ }^{2}=$ $78.70 \%$

$\mathrm{Y}_{3}=1.40 \mathrm{E}+01+6.92 \mathrm{E}-06 \alpha \beta^{2}-1.04 \mathrm{E}-05 \alpha \beta \gamma+2.18 \mathrm{E}-$ $05 \alpha \gamma^{2}-6.39 \mathrm{E}-06 \alpha^{2} \gamma+1.68 \mathrm{E}-05 \alpha \gamma^{2}, \mathrm{R}_{\mathrm{adj}}^{2}=83.60 \%$

$\mathrm{Y}_{4}=-1.75-5.51 \mathrm{E}-06 \alpha \gamma^{2}+2.59 \mathrm{E}-07 \alpha \beta^{2}+1.23 \mathrm{E}-01 \gamma+$ $5.23 \mathrm{E}-06 \alpha^{2} \gamma-5.34 \mathrm{E}-04 \gamma^{2}-4.63 \mathrm{E}-07 \beta \gamma^{2}, \mathrm{R}_{\mathrm{adj}}^{2}=94.50 \%$

$\mathrm{Y}_{5}=9.17 \mathrm{E}-01-3.15 \mathrm{E}-04 \alpha \beta+4.13 \mathrm{E}-04 \beta \gamma-5.88 \mathrm{E}-$ $06 \alpha \beta \gamma+1.72 \mathrm{E}-01 \alpha+7.69 \mathrm{E}-02 \gamma-6.43 \mathrm{E}-06 \alpha \gamma^{2}-1.92 \mathrm{E}-$ $04 \beta^{2}+3.52 \mathrm{E}-06 \alpha \beta^{2}, \mathrm{R}_{\mathrm{adj}}^{2}=99.50 \%$

$\mathrm{Y}^{-1}{ }_{6}=1.31+6.28 \mathrm{E}-04 \alpha \beta-1.16 \mathrm{E}-04 \beta^{2}-1.01 \mathrm{E}-05 \alpha^{2} \beta+$ $1.04 \mathrm{E}-06 \alpha^{2} \gamma+1.93 \mathrm{E}-06 \alpha \beta^{2}, \mathrm{R}_{\mathrm{adj}}^{2}=78.70 \%$

$\mathrm{Y}_{7}=4.47 \mathrm{E}+01+3.44 \mathrm{E}-05 \alpha^{2} \beta+8.61 \mathrm{E}-03 \gamma^{2}-\gamma-3.65 \mathrm{E}$

$05 \alpha \beta \gamma+1.16 \mathrm{E}-05 \beta \gamma^{2}, \mathrm{R}_{\mathrm{adj}}^{2}=60.00 \%$

$\mathrm{Y}_{8}=3.54+4.43 \mathrm{E}-06 \alpha \gamma^{2}-5.38 \mathrm{E}-05 \beta^{2}+6.91 \mathrm{E}-03 \beta+$

$1.40 \mathrm{E}-06 \alpha \beta \gamma-4.21 \mathrm{E}-02 \alpha-4.21 \mathrm{E}-04 \gamma^{2}, \mathrm{R}_{\mathrm{adj}}{ }^{2}=86.90 \%$

where $Y_{1}, Y_{2}, Y_{3}, Y_{4}, Y_{5}, Y_{6}, Y_{7}$ and $Y_{8}$ are drying rate, ash content, crude fibre, crude fat, crude protein, bulk density, least gelation concentration (LGC) and water absorption capacity (WAC) respectively and $\alpha, \beta$ and $\gamma$ are osmotic solution concentration, osmotic process duration and drying temperature respectively.

\section{Model characterization}

The measured (observed) outputs of drying rate and post-drying quality attributes of okra were compared with the predicted values from the developed process models. The two sets of data were plotted on the same graph to see how favourably compared and two of the curves are and the plots are shown in Figs. 2 and 3. A little or no difference could be noticed in the trend of the paired curves generated (Fig. 2). This showed that all the predicted values of drying rate, ash content, crude fibre, crude fat, crude protein and water absorption capacity (WAC) were favourably compared with the observed values. Therefore, the models reliably predicted the drying characteristics of okra considerably in terms of these output parameters.

However, Fig. 3 revealed that there are differences in the trend of paired curves generated indicating that the observed values of bulk density and least gelation concentration (LGC) were not compared favourably with the predicted values. Therefore, bulk density and least gelation concentration of dried okra were not sufficiently predicted by the models. The impact of osmotic dehydration pre-treatments and drying temperature on water loss and drying rate (rate of water removal from the product) were in agreement with previous reports in the literature (Taiwo et al., 1997; Taiwo et al., 2003a; 2003b; Singh et al., 2006a; 2006b; Singh et al., 2008a; 2008b).

Drying rate, crude fibre, and crude fat and crude protein increased with increases in the process variables (osmotic solution concentration, osmotic process duration and drying temperature). On the other hand, ash content and water absorption capacity (WAC) decreased with increase in osmotic solution concentration, osmotic process duration and drying temperature. Bulk density and least gelation concentration of the dried okra appeared not to be affected by the osmotic dehydration pretreatments and drying temperature.

\section{Model validation}

In order to validate the process model, both the observed and predicted values of process outputs were subjected to paired t-test and the results are as shown in Table 1. The coefficient of correlation were 0.982 (for drying rate), 0.990 (for ash content), 0.921 (for crude fibre), 0.974 (for crude fat), 0.998 (for crude protein), 0.449 (for bulk density), 0.770 (for least gelation concentration (LGC)) and 0.938 (for water absorption capacity (WAC)).

All the process outputs (except bulk density and least gelation concentration) gave high level of correlation. The high correlation coefficients showed that the model was able to describe the drying characteristics of okra and also predicted the drying rate, ash content, crude fibre, crude fat, crude protein and water absorption capacity of the dried okra with high degree of reliability. The low level of correlation as between the observed and predicted values of bulk density and least gelation concentration of the dried okra showed that the developed model could not sufficiently predict these process output parameters.

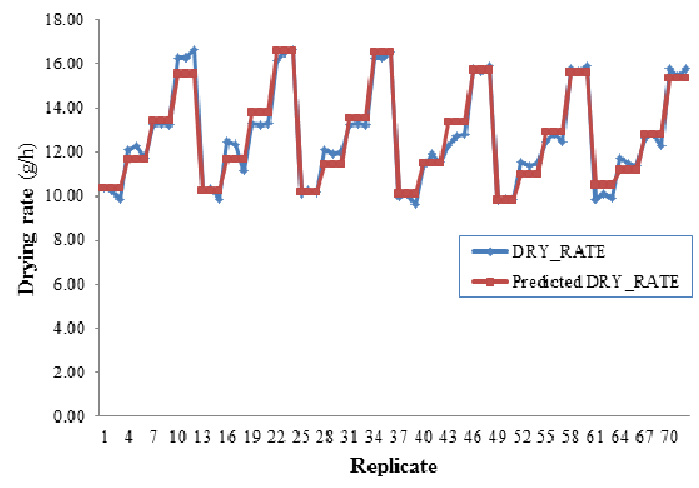

Fig. 2. Comparison of the observed and predicted drying rate of okra 
496

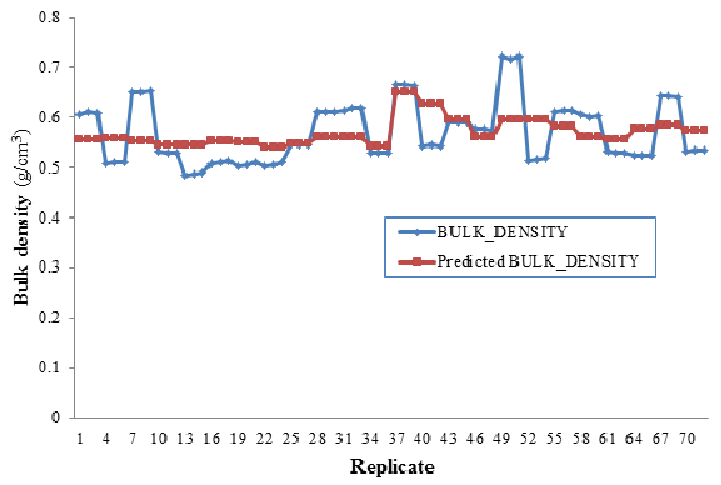

Fig. 3. Comparison of the observed and predicted bulk density of okra

Process optimization

The optimum values of the process variables (osmotic solution concentration, osmotic process duration and drying temperature) and optimized value of process outputs (drying rate and post-drying qualities) are presented in Table 2. In order to maximize drying rate of okra, osmotic solution concentration, osmotic process duration and dying temperature of $40{ }^{\circ} \mathrm{Brix}, 149.10 \mathrm{~min}$ and $80^{\circ} \mathrm{C}$ respectively must be combined to give the optimum drying rate of 16.69 $\mathrm{g} / \mathrm{h}$. For ash content, a combination of $40{ }^{\circ}$ Brix osmotic solution concentrations, $180 \mathrm{~min}$ osmotic process duration and drying temperature of $50{ }^{\circ} \mathrm{C}$ resulted to the optimum value of $3.76 \%$.

An optimum value of $29.65 \%$ was obtained for crude fibre at an osmotic solution concentration of $60{ }^{\circ}$ Brix, osmotic process duration of $180 \mathrm{~min}$ and drying temperature of $80{ }^{\circ} \mathrm{C}$. The crude fat content of okra has $4.03 \%$ as its optimum value and this corresponds to a combination of $60{ }^{\circ}$ Brix osmotic solution concentration, 180 min osmotic process duration and $74.60{ }^{\circ} \mathrm{C}$ drying temperature. An osmotic solution concentration of 60 ${ }^{\circ}$ Brix, osmotic process duration of $60 \mathrm{~min}$ and drying temperature of $80{ }^{\circ} \mathrm{C}$ should be selected to give the optimum crude protein of $14.12 \%$.

Bulk density requires an osmotic solution concentration of $47.75^{\circ}$ Brix, osmotic process duration of $144.57 \mathrm{~min}$ and drying temperature of $80{ }^{\circ} \mathrm{C}$ to give the optimum value of $0.50 \mathrm{~g} / \mathrm{cm}^{3}$. An optimum value of $23.84 \%$ was obtained for least gelation concentration (LGC) at an osmotic solution concentration of $60^{\circ} \mathrm{Brix}$, osmotic process duration of 180 min and drying temperature of $80^{\circ} \mathrm{C}$. The water absorption capacity (WAC) of okra has $1.68 \%$ as its optimum value and this corresponds to a combination of $40^{\circ}$ Brix osmotic solution concentration, 90.19 osmotic process duration and $50{ }^{\circ} \mathrm{C}$ drying temperature.

\section{Practical application}

Preservation of okra and quality retention could be best achieved if it is processed to a powdery form immediately after harvest. The process involves drying okra to an intermediate and shelf-stable moisture content and then mill the dried product to a powdery form. Since okra is a food product, drying temperature and other process parameters should be carefully controlled in order not to destroy or denature the sensory characteristics such as flavour, aroma and other quality attributes.

The result of this research provides useful information for process monitoring, control and observation during the drying of okra. The model can be used for optimizing the efficiency of commercial food drying process and the performance of commercial food dryers. An important aspect of this research is the osmotic dehydration process which is a new technology for treating fruits and vegetables prior to drying. Therefore, a food drying process based on the result of this research would ensure a high process efficiency and appreciable retention of product quality.

Table 1. Pair wise test comparing observed and predicted values of process outputs

\begin{tabular}{cccccc}
\hline Pair samples & Mean & MSE & t & DF & $\begin{array}{c}\text { Significance } \\
(2 \text {-tailed) }\end{array}$ \\
\hline Obs-Pre $^{\mathrm{a}}$ & 0.000417 & 0.050156 & 0.008 & $\begin{array}{c}\text { Correlation } \\
\text { coefficient }\end{array}$ & 0.993 \\
Obs-Pre $^{\mathrm{b}}$ & 0.000042 & 0.011359 & 0.004 & 71 & 0.982 \\
Obs-Pre $^{\mathrm{c}}$ & 0.000972 & 0.160422 & 0.006 & 71 & 0.997 \\
Obs-Pre $^{\mathrm{d}}$ & 0.000000 & 0.008861 & 0.000 & 71 & 0.995 \\
Obs-Pre $^{\mathrm{e}}$ & -0.001014 & 0.011150 & -0.091 & 71 & 0.990 \\
Obs-Pre $^{\mathrm{f}}$ & 0.000042 & 0.006377 & 0.007 & 71 & 0.928 \\
Obs-Pre $^{\mathrm{g}}$ & 0.000417 & 0.221463 & 0.002 & 71 & 0.995 \\
Obs-Pre $^{\mathrm{h}}$ & -0.000417 & 0.012134 & -0.034 & 71 & 0.999 \\
\hline
\end{tabular}

Obs- Observed; Pre- Predicted; a- drying rate; b- ash content; c- crude fiber; d- crude fat; e- crude protein; f- bulk density; g- least gelation concentration (LGC); hwater absorption capacity (WAC)

Table 2. Optimized values of process variables and process output

\begin{tabular}{|c|c|c|c|c|c|}
\hline Output parameters & Temperature $\left({ }^{\circ} \mathrm{C}\right)$ & $\begin{array}{c}\text { Osmotic solution } \\
\text { concentration }\left({ }^{\circ} \text { Brix }\right)\end{array}$ & $\begin{array}{l}\text { Osmotic process } \\
\text { duration }(\mathrm{min})\end{array}$ & Optimized value & Nature of solution \\
\hline Drying rate $(\mathrm{g} / \mathrm{h})$ & 80.00 & 40.00 & 149.10 & 16.69 & Maximized \\
\hline Ash content (\%) & 50.00 & 40.00 & 180.00 & 3.76 & Maximized \\
\hline Crude fiber (\%) & 80.00 & 60.00 & 180.00 & 29.65 & Maximized \\
\hline Crude fat (\%) & 74.60 & 60.00 & 180.00 & 4.03 & Maximized \\
\hline Crude protein (\%) & 80.00 & 60.00 & 60.00 & 14.12 & Maximized \\
\hline Bulk density $\left(\mathrm{g} / \mathrm{cm}^{3}\right)$ & 80.00 & 47.76 & 144.57 & 0.50 & Maximized \\
\hline LGC (\%) & 80.00 & 60.00 & 180.00 & 23.84 & Maximized \\
\hline WAC (\%) & 50.00 & 40.00 & 90.19 & 1.68 & Maximized \\
\hline
\end{tabular}

Process variables range $\left(40 \leq \mathrm{X}_{1} \leq 60 ; 60 \leq \mathrm{X}_{2} \leq 180 ; 50 \leq \mathrm{X}_{3} \leq 80\right)$ 


\section{Conclusions}

The empirical models developed to relate the drying rate and post-drying qualities of okra to the osmotic dehydration pretreatments and drying temperature described the dying characteristics of okra sufficiently to predict the output parameters. Therefore these models can be applied for industrial drying of okra under different process pretreatments and under different drying conditions. Further studies should be carried out on the factors that affect the storability of dried okra for long-time storage and preservation.

\section{References}

Afify AMR, El-Beltagi HS, AbdEl-Salam SM, Omran AA (2015). Effect of soaking, cooking, germination and fermentation on physical properties and sensory evaluation of sorghum biscuits. Notulae Scientia Biologicae $7(1): 129-135$

Alqasoumi SI (2012). 'Okra' Hibiscus esculentus L.: A study of its hapatoprotective activity. Saudi Pharmaceutical Journal 20(2):135-141.

Anwar F, Rashid U, Ashraf M, Nadeem M (2010). Okra (Hibiscus esculentus) seed oil for biodiesel production. Applied Energy 87(3):779785.

Babatunde RO, Omotesho OA, Sholotan OS (2007). Socio-economic characteristics and food security status of farming household in Kwara State, North-Central Nigeria. Pakistan Journal of Nutrition 6(1):49-58.

Doymaz I (2005). Drying characteristics and kinetics of okra. Journal of FoodEngineering69(3):275-279.
Mohebbi S, Mostofi Y, Zamani Z, Najafi F (2015). Influence of modified atmosphere packaging on storability and postharvest quality of Cornelia cherry (Cornusmas L.) fruits. Notulae Scientia Biologicae 7(1):116-122.

Olaniyan AM, Omoleyomi BD (2013). Characteristics of okra under different process pretreatments and different drying conditions. Journal ofFood Processing and Technology 4(6):2-6.

Singh B, Panesar PS, Nanda V (2006a). Application of response surface methodology for the osmotic dehydration of carrots. Journal of Food Process Engineering 29(6):592-614.

Singh B, Panesar PS, Nanda V, Gupta AK, Kennedy JF (2006b). Sorption isotherm behavior of osmo-convectively dehydrated carrot cubes. Journal of Food Processing and Preservation 30(6):684698.

Singh B, Panesar PS, Nanda V (2008a). Optimization of osmotic dehydration process of carrot cubes in sucrose solution. Journal of Food Process Engineering 31(1):1-20.

Singh B, Panesar PS, Nanda V (2008b). Osmotic dehydration kinetics of carrot cubes in sodium chloride solution. International Journal of Food Science and Technology 43(8):1361-1370.

Taiwo KA, Akanbi CT, Ajibola OO (1997). Establishing processing conditions for canning cowpea seeds in tomato sauce. International Journal of Food Science and Technology 32(4):312-324.

Taiwo KA, Angerseach A, Knorr D (2003a).Effect of pulsed electric field on quality factors and mass transfer during osmotic dehydration of apples. Journal of Food Process Engineering 26(1):31-48.

Taiwo KA, Eshtiaghi MN, Ade-Omowaye BIO, Knorr D (2003b). Osmotic dehydration of strawberry halves: Influence of osmotic agents and pretreatment methods on mass transfer and product characteristics. International Journal of Food Science and Technology 38(6):693-707. 